\title{
Inhibition of airway proteases in cystic fibrosis lung disease
}

\author{
M. Griese*, M. Kappler*, A. Gaggar and D. Hart|*
}

ABSTRACT: Progressive lung disease determines the morbidity and mortality of cystic fibrosis (CF) patients.

CF lung disease is characterised by endobronchial inflammation sustained by bacterial infections and an ongoing accumulation of airway neutrophils. Activated or necrotic neutrophils liberate proteases that cause damage to structural, cellular and soluble components of the pulmonary microenvironment.

Among various proteases released by airway cells, elastase is considered to play the major role in CF lung disease. Based on this concept, several therapeutic approaches have been developed to inhibit free elastolytic activity, including small synthetic chemical compounds, semi-synthetic inhibitors and natural inhibitors of free elastase.

The present review summarises and discusses the pathophysiological rationales, methodological requirements and clinical implications of inhibition of airway proteases in cystic fibrosis lung disease.

KEYWORDS: Antiproteases, antitrypsin, cystic fibrosis, elastase, lung disease, proteases

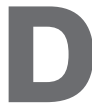
espite various therapeutic advances, $>90 \%$ of cystic fibrosis (CF) patients still die due to respiratory failure. The airways of the majority of patients with CF are chronically infected with bacterial pathogens, especially Pseudomonas aeruginosa [1]. As a consequence, large numbers of neutrophils accumulate in $\mathrm{CF}$ airways, resulting in sustained endobronchial inflammation [2]. The duration and intensity of the airway inflammation, however, appear to be much more pronounced than required for the removal of the offending pathogens. This excessive inflammatory response is probably related to the disease-causing mutations in the CF transmembrane conductance regulator (CFTR) gene. However, the exact pathogenic mechanisms involved have not been completely elucidated. Increased mucus viscosity, impaired local host defence, and innate and adaptive immune mechanisms seem to be involved. Other mechanisms, such as gain of function resulting from mutated CFTR causing an enhanced endoplasmic reticulum stress response and pro-inflammatory activity may also play a role [3]. As a result, CF airways exhibit sustained inflammation that causes harm to the lungs, leading to irreversible collateral damage caused by chronic airway destruction and remodelling.
Despite several lines of pathophysiological evidence to support the concept of an overwhelming pro-inflammatory response in CF airways [2], only a few clinical studies have successfully established anti-inflammatory strategies in patients with CF lung disease, such as the application of ibuprofen [4-6] and recombinant human DNase [7]. Other studies have demonstrated the ineffectiveness or the occurrence of adverse side-effects of approaches involving inhaled steroids [8] and a leukotriene (LT)B $\mathrm{B}_{4}$ antagonist [9]. A major difficulty in evaluating anti-inflammatory treatments in clinical trials remains selection of appropriate outcome measures (table 1). Possible outcome parameters include lung function (spirometry), bronchoalveolar lavage (BAL) fluid (BALF) analysis, sputum analysis, sputum microbiology, chest computed tomography (CT), infant and toddler lung function such as measured via lung clearance index, frequency of pulmonary exacerbations, quality-of-life assessments, aerosol deposition and clinical symptom scores. The various outcome measures should be considered according to the phase of the clinical trial, as depicted in table 1 . The references given in table 1 indicate studies in which the respective outcome measures have been used.

\section{AFFILIATIONS}

${ }^{*}$ Children's Hospital of Ludwig

Maximilians University, Munich,

Germany.

\#University of Alabama at

Birmingham, Birmingham, AL, USA.

CORRESPONDENCE

M. Griese

Ludwig Maximilians University

Children's Hospital

Lindwurmstr. 4

D-80337 Munich

Germany

Fax: 498951607872

E-mail: matthias.griese@med.uni-

muenchen.de

Received:

November 052007

Accepted after revision:

March 312008

STATEMENT OF INTEREST

None declared. 
Traditionally used pulmonary outcomes, such as forced expiratory volume in one second (FEV1), reflect major changes in pulmonary function but are considered less appropriate for monitoring more subtle changes. Therefore, novel outcome parameters, such as CT scan results, may become increasingly important but still require more extensive validation. Other outcome measures, such as exacerbation rate or quality of life, might additionally help in the monitoring of CF patients' lung disease, and should be considered when performing clinical studies. Inflammatory outcome markers in blood, sputum or urine have been shown to be especially helpful in the assessment of antibiotic treatment [20-22].

Therefore, it remains an ongoing challenge for clinical researchers to define and carefully evaluate outcome measures that permit the monitoring of airway inflammation and investigation of the effect of anti-inflammatory interventions in patients with CF lung disease. For a more extensive discussion concerning outcome measures in clinical trials of $\mathrm{CF}$, see a previous review [23].

\section{PROTEASE-ANTIPROTEASE IMBALANCE IN CF AIRWAYS}

Previous studies have demonstrated that CF airway fluids contain large amounts of pro-inflammatory mediators, especially interleukin (IL)-8, which attract large numbers of neutrophils into the airways [24]. This should provide an initial line of immune defence against bacterial pathogens. However, the recruited airway neutrophils seem unable to clear the local pathogens, but instead accumulate, undergo secondary necrosis and liberate their intracellular components, such as serine proteases. Serine proteases are physiologically important in both intracellular $[25,26]$ and peri-/extracellular

\begin{tabular}{|c|c|c|c|c|c|}
\hline \multirow{3}{*}{\multicolumn{2}{|c|}{ TABLE 1}} & \multicolumn{4}{|c|}{ of clinical trials in cystic } \\
\hline & & \multicolumn{3}{|c|}{ Phase $^{\#}$} & \multirow[t]{2}{*}{ [Ref.] } \\
\hline & & $\mathbf{I}$ & II & III & \\
\hline \multicolumn{3}{|c|}{ Quality of life } & ++ & +r+ & {$[10]$} \\
\hline \multicolumn{2}{|c|}{$\begin{array}{l}\text { Frequency of pulmonary } \\
\text { exacerbations }\end{array}$} & & ++ & +H & [11] \\
\hline \multicolumn{2}{|c|}{$\begin{array}{l}\text { Infant and toddler lung function, } \\
\text { including } \mathrm{LCl}\end{array}$} & & +++ & & [12] \\
\hline \multicolumn{2}{|c|}{ Chest CT } & & +r+ & +r+ & [13] \\
\hline \multicolumn{2}{|c|}{ Aerosol deposition } & +++ & ++ & & [14] \\
\hline \multicolumn{2}{|c|}{$\begin{array}{l}\text { Bronchoalveolar lavage } \\
\text { fluid analysis }\end{array}$} & +++ & ++ & & [15] \\
\hline \multicolumn{2}{|c|}{ Sputum analysis } & ++ & ++ & & [16] \\
\hline \multicolumn{2}{|c|}{ Symptom score } & +++ & n+ & +++ & [17] \\
\hline \multicolumn{2}{|c|}{ Lung function (spirometry) } & +++ & n+ & +H & [18] \\
\hline \multicolumn{2}{|c|}{ Sputum microbiology } & +++ & +r+ & +r+ & [19] \\
\hline
\end{tabular}

LCl: lung clearance index; CT: computed tomography. ++: moderate; +++ optimal. ${ }^{\#}$ : scale (++ or +++) indicates degree to which outcome measure is suited to clinical trial phase; " : study in which the outcome measure has been implemented. killing, as recently demonstrated by the identification of neutrophil extracellular traps that capture bacteria and facilitate a close interaction of the pathogen with released proteases, finally resulting in bacterial killing [27-30].

In chronic disease conditions, the amount of proteases exceeds the neutralising capacity of antiproteases. The proteaseantiprotease imbalance hypothesis of chronic lung disease suggests that protease levels in the lower respiratory tract are a major determinant of pulmonary damage and emphysema [31]. This hypothesis is corroborated by the finding that disease severity in patients with chronic bronchitis and pulmonary emphysema is positively related to pulmonary protease load and inversely related to the antiprotease shield [32].

In CF patients, several studies have found a correlation between proteases on the one hand and tissue damage and disease severity on the other [33-36]. The local proteaseantiprotease imbalance in CF airway fluids has been demonstrated to be established by the age of $1 \mathrm{yr}$, and is probably sustained chronically thereafter [33]. The protease-antiprotease imbalance in CF airways is probably not due to an intrinsic CFTR-associated lack of antiproteases since $\mathrm{CF}$ patients exhibit normal serum and bronchoalveolar levels of antiproteases [33].

Among the variety of proteases released by disrupted neutrophils, human leukocyte elastase (HLE) is considered the major factor causing harm to the surrounding pulmonary microenvironment [37]. The scanty data available demonstrate that the vast majority of the elastinolytic activity in CF sputum can be attributed to the neutrophil-derived HLE, when assessed in terms of micrograms of elastin degraded per millilitre of solution per minute. Accordingly, HLE was responsible for $90 \%$ of the activity, protease 3 for $7 \%$ and soluble mediators released from macrophages, along with P. aeruginosa-derived proteases, made up 3\% [38]. Nevertheless, it is very difficult to compare the various proteolytic activities of different neutrophil-derived enzymes directly, since the relevance of the target structures and different microcompartments within the airspaces are unknown. Free HLE degrades several extracellular matrix components, such as elastin, collagen, proteoglycans, fibronectin and other proteins, thereby causing pulmonary tissue destruction [31, 39-43]. In addition, HLE is capable of inactivating the antiprotease tissue inhibitor of metalloproteases (TIMP) and elafin [44], which, in turn, amplify overall proteolytic activity in situ. For a more extensive discussion of HLE functions, reference should be made to previously published reviews [45-48].

With ongoing CF lung disease, a prolonged endobronchial protease activity (PEPA) is established. This term has been chosen since, in contrast to acute lung disease, in which a temporarily increased extracellular protease activity can also be observed, the protease-antiprotease imbalance in CF is sustained for an ongoing period of time, and thus is prolonged. PEPA has been documented very early in CF airways by means of BAL in children with CF diagnosed by neonatal screening and regular follow-up [15, 49]. These studies suggested a close relationship between inflammation and infection. However, the causative sequence between pulmonary infection and airway inflammation is still incompletely 
understood. In particular, the longitudinal course of PEPA, as well as the effect of antibiotic or nonantibiotic treatments on PEPA, are yet to be characterised.

\section{PEPA INACTIVATES SOLUBLE AND CELLULAR COMPONENTS OF THE PULMONARY IMMUNE SYSTEM}

Apart from the issues that remain unclear, there is a broad consensus that PEPA causes harm to various structural, cellular and soluble components of the lung [50]. In the following sections, attention is drawn to the mechanisms by which PEPA inactivates the pulmonary host defence and thereby permits pathogens to colonise $\mathrm{CF}$ airways. In order to provide an overview of the proteins targeted by HLE activity, they have been divided into the soluble and cellular targets of the pulmonary immune system, and are summarised and discussed below.

\section{Soluble immune targets}

HLE has been found to affect a variety of soluble components of the pulmonary immune response (fig. 1a-d). In particular, the complement opsonic $\mathrm{C} 3$ fragment $\mathrm{iC} 3 \mathrm{~b}$ is cleaved on the surface of bacteria by HLE [51]. HLE has the capacity to cleave immunoglobulins, resulting in FC and Fab fragments and leading to a decrease in both phagocytosis and killing of $P$. aeruginosa [52]. HLE has also been shown to degrade surfactant protein (SP)-A and -D, which impairs the innate host defence of the bronchoalveolar space [53-56]. HLE causes further changes in the host defence response seen in CF by cleaving and inactivating bacterial flagellin [57], and also by degradation and inactivation of annexin I, a calcium-dependent phospholipid-binding protein thought to have antiinflammatory properties [58]. In addition, HLE seems to be a potent proenzyme activator and inducer of gene expression of matrix metalloprotease (MMP)-2 and cathepsins [59, 60]. The upregulation of MMP-2 activity may then lead to cleavage and inactivation of further key immune proteins, such as $\beta$ defensins and lactoferrin. HLE was found to be an activator of MMP-9 [61] and an inactivator of the MMP inhibitor TIMP-1 [44], resulting in an imbalance in MMP and TIMP. Recently, these findings have been confirmed at concentrations of HLE demonstrated in CF lung disease [62, 63]. The increased activation of MMP-9 in CF lung disease has many possible downstream inflammatory effects, including activation of latent transforming growth factor (TGF)- $\beta$ ) [64] and the possible liberation of collagen fragments chemotactic for neutrophils [65]. HLE may also contribute to the perpetuation of lung inflammation by degrading complement and releasing $\mathrm{C} 5 \mathrm{a}$, a potent chemoattractant for neutrophils, and by increasing airway serous cell mucus production $[66,67]$.

\section{Cellular targets}

The main cellular targets of PEPA are shown in figure 1e-h. Phagocytosis of apoptotic neutrophils results in increased production of TGF- $\beta$, which, in turn, reduces the production of pro-inflammatory cytokines by neutrophils. Alveolar macrophages remove apoptotic neutrophils from the respiratory tract via phosphatidylserine receptor (PSR/CD36), thereby facilitating the resolution of inflammatory processes $[68,69]$. Free HLE has been found to cleave PSRs from alveolar macrophages, which impairs the clearance of apoptotic cells [70]. As a result, the HLE-mediated impairment of phagocytosis results in decreased production of TGF- $\beta$ and amplification of proinflammatory responses [71]. Furthermore, HLE was found to induce IL-8 production by bronchial epithelial cells and $\mathrm{LTB}_{4}$ expression in macrophages [72, 73]. The induction of IL-8 expression was found to be mediated via an IL-1 receptorassociated kinase 1/myeloid differentiation factor (MyD)88)/ nuclear factor- $\gamma$-dependent pathway, suggesting the involvement of Toll-like receptors (TLRs) [72]. Moreover, HLE cleaves complement receptor (CR)1 [51, 74], tumour necrosis factor receptor (TNFR)II [75], CD43 [76], CD16 (low-affinity immunoglobulin G receptor (Fc $\gamma \mathrm{RIII})$ ) [76] and, as demonstrated recently, the high-affinity IL-8 receptor CXC chemokine receptor (CXCR) 1 [77] on the neutrophil surface. By means of these mechanisms, HLE disables bacterial killing (CXCR1), phagocytosis (CR1 and CD16), adhesion (TNFRII) and spreading/aggregation (CD43) of neutrophils. With respect to adaptive immunity, HLE cleaves CD4 and CD8 on T-cells, which reduces the cytotoxicity and cytokine production by $\mathrm{T}$ cells [78]. HLE was also found to cleave CD14 on fibroblasts and monocytes, resulting in decreased responsiveness to lipopolysaccharide [79, 80].

Taken together, unopposed HLE is able to undermine several key components of the innate and adaptive pulmonary immune response, which, in combination, results in impairment of pulmonary host defence in CF airways. In particular, impairment of the complement system [51, 74] and IL-8/ CXCR1-mediated neutrophil functions [77] may be of major relevance since both mechanisms were found to be operative in vitro, as well as in humans with CF lung disease in vivo. BERGER et al. [74] showed that neutrophils upregulate both CR1 and CR3 upon activation with $N$-formyl-methionyl-leucyl-phenylalanine (f-MLP). BALF neutrophils isolated from CF patients showed increased CR3 expression, similar to f-MLP-stimulated blood cells, but CR1 was decreased on BALF neutrophils compared to the f-MLP-stimulated blood cells. The loss of CR1 on CF BALF cells could be reproduced by treating isolated neutrophils with HLE, whereas CR3 was resistant to HLE. In a subsequent study, the same group demonstrated that the complement fragment $\mathrm{iC} 3 \mathrm{~b}$ on the surface of opsonised bacteria is cleaved by proteolytic activity and that this mechanism is operative ex vivo [51]. Taken together, the loss of opsonins on bacteria, as well as cleavage of CR1 on airway neutrophils, results in a local pulmonary opsonin-receptor mismatch that impairs phagocytosis of bacterial pathogens in CF lung disease [81].

It was recently found that, besides the elastase-mediated impairment of the complement system, IL-8-mediated neutrophil functions are also disabled in CF lung disease [77]. IL-8 mediates its functions via two receptors, CXCR1 and CXCR2 [82]. It was demonstrated that CXCR1 but not CXCR2 conveys oxidative and nonoxidative antibacterial neutrophil functions [77]. However, CXCR1 is cleaved in CF airways, which impairs the stimulating effect of IL- 8 on bacterial killing by airway neutrophils. Soluble cleaved CXCR1 fragments were further found to stimulate IL-8 production in bronchial epithelial cells, mediated via a TLR2/MyD88 pathway. Inhibition of proteases by inhalation of $\alpha_{1}$-antitrypsin $\left(\alpha_{1}\right.$-AT) in vivo largely prevented CXCR1 and CR1 cleavage and improved bacterial clearance in CF patients in vivo. 
a)
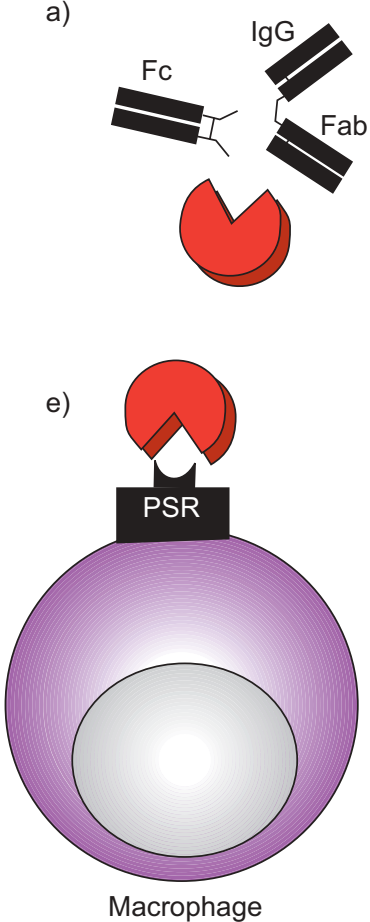

b)

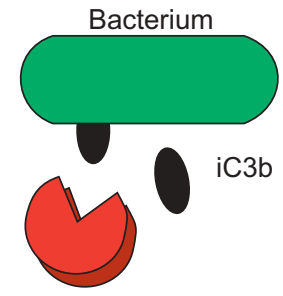

f)

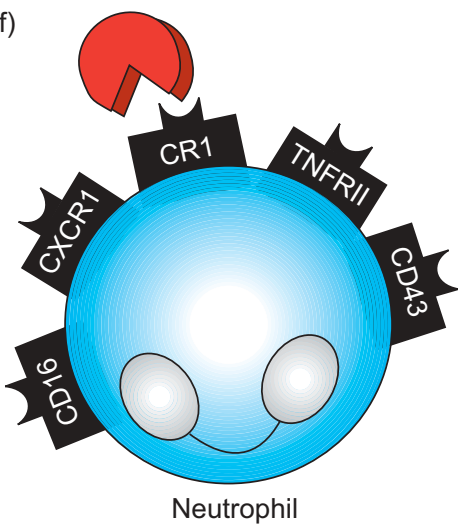

c)

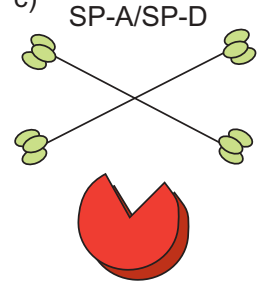

g)

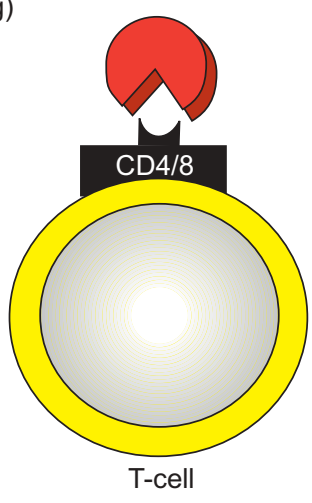

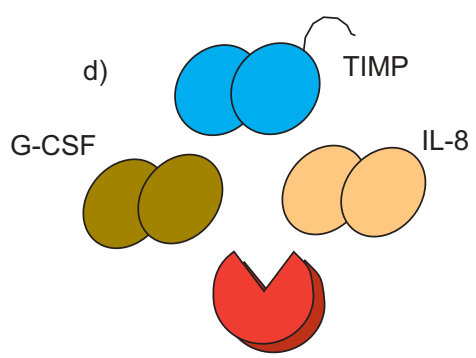

h)

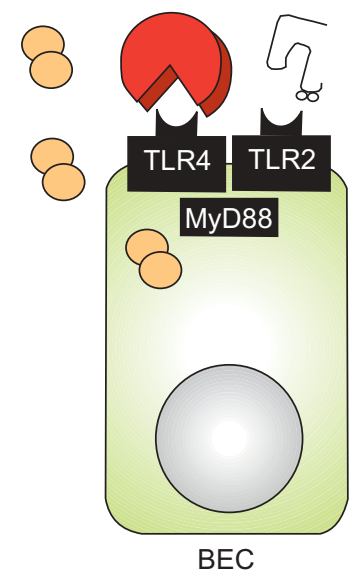

FIGURE 1. Effects of free neutrophil elastase (red) on: a-d) soluble; and e-h) cellular components of the pulmonary immune system. a) Elastase cleaves immunoglobulin (Ig)G, resulting in shed Fc and Fab fragments. It: b) cleaves iC3b on opsonised bacteria; and c) degrades surfactant proteins (SP)-A and -D, thereby impairing the innate host defence in the bronchoalveolar space. d) Elastase processes granulocyte colony-stimulating factor (G-CSF), tissue inhibitor of metalloproteinase (TIMP) and interleukin (IL)-8. These events lead to an inhibition of growth processes (G-CSF), increased activity of matrix metallproteases and a more active form of IL-8 as chemoattractant on neutrophils. e) Elastase cleaves phosphatidylserine receptors (PSRs) from alveolar macrophages, thereby impairing the clearance of apoptotic cells from the bronchoalveolar space. f) It cleaves complement receptor (CR)1, CD16, tumour necrosis factor receptor (TNFR)II, CXC chemokine receptor (CXCR)1 and CD43 on the neutrophil surface, thereby disabling the bacterial phagocytosis (CR1, CD16), killing capacity (CXCR1), adhesion (TNFRII) and aggregation (CD43) of neutrophils. g) Elastase further cleaves CD4 and CD8 on T-cells, which reduces cytotoxicity and cytokine production. h) In bronchial epithelial cells (BECs), elastase, as well as cleaved soluble CXCR1 fragments, induce IL-8 production mediated via Toll-like receptor (TLR) 2/4 and the common adapter protein, myeloid differentiation factor 88 (MyD88), thereby amplifying the pro-inflammatory neutrophil influx into cystic fibrosis airways.

When viewed in combination, the cleavage of CR1 and $\mathrm{iC} 3 \mathrm{~b}$, as well as CXCR1, impairs both complement-mediated phagocytosis and the direct antibacterial functions of neutrophils, and may act synergistically to disarm the innate immune response in CF airways in vivo.

\section{ASSESSMENT OF PEPA}

Since the protease-antiprotease system is complex and involves several interdependencies with nonprotease factors, the present review focuses primarily on HLE and its natural inhibitor $\alpha_{1}$-AT. Most commonly, HLE is measured using a chromogenic activity assay that is standardised and sensitive [83]. The amount of $\alpha_{1}$-AT present is determined by immunodetection, either by ELISA or via immunoprecipitation. $\alpha_{1}$-AT can be inactivated by oxidation and binding to HLE. Therefore, in addition to the amount of $\alpha_{1}$-AT that is bound to HLE in complexes, its functional capacity to neutralise HLE can also be assessed. Since preanalytical issues, such as sample type, sample preparation and further processing, are critical to the accurate assessment of PEPA, they are addressed in the following sections. In particular, the use of BAL and sputum are compared, and the shortcomings and pitfalls of each method are discussed below.

\section{Bronchoalveolar lavage}

Bronchoscopy with BAL can be performed in patients of all age groups (infants and children requiring general anaesthesia or deep sedation), and localised areas within the lungs can be precisely targeted [84]. Depending upon the volume of lavage fluid instilled, either more proximal $(e . g .1 \mathrm{~mL} \cdot \mathrm{kg}$ body weight $^{-1}$ ) or more distal areas (e.g. 2-4 $\mathrm{mL} \cdot \mathrm{kg}$ body weight ${ }^{-1}$ ) are reached. However, it is an invasive procedure. The rate of adverse events, mostly fever or localised infiltration, might increase with the volumes instilled and the severity of the underlying lung disease. A further consideration when assessing the overall proteolytic condition of the airways of $\mathrm{CF}$ patients is that CF lung disease is typically more pronounced in the bronchi and bronchioles, whereas BAL samples both bronchial and alveolar compartments.

The BALF recovered should be freed of mucus by filtration, followed by the separation of cells from a cell-free supernatant by centrifugation. The supernatant is routinely used for assay of HLE activity. The normal range of HLE activity expected in human volunteers (but not in children) has been determined (discussed further later). None or only minor free elastolytic activity is normally detectable in healthy individuals, whereas anti-elastolytic reserve $\left(\alpha_{1}-\mathrm{AT}\right)$ is physiologically present. 


\section{Induced or spontaneous sputum}

By inhalation of hypertonic agents, such as $6 \%$ sodium chloride, sputum can be induced in almost every subject. The technique of sputum induction is safe and now widely used as a therapeutic and diagnostic option [16, 85, 86]; potential broncho-obstruction induced by the procedure may be alleviated by pretreatment with a bronchodilator. The recovery of the sputum, however, depends heavily upon the cooperation of the individual. The majority of young children aged $<6$ yrs do not reliably spit out sputum that is induced in their bronchial tree, but instead frequently swallow it. Therefore, this technique was considered to be reliably used only in those aged $\geqslant 6$ yrs. However, a recent study reported the successful application of sputum induction in CF children with a median age of 3 yrs [87]. Despite further studies being required for the assessment of practicability and safety in this young age group, the latter study suggested that sputum induction can also be applied in CF infants aged $<6$ yrs.

Nevertheless, several limitations should be considered when using sputum. First, induced sputum is thought to be more variable than BALF, especially when using serial sampling, since serial specimens may not sample the same region within the lung. This is of particular relevance in CF lung disease since CF inflammation seems to inhomogeneously affect different pulmonary sites [88]. Secondly, sputum is a complex network of material expelled from the lungs, and, as such, is very difficult to separate into its original components without influencing them. Usually sputum plugs are selected and dissolved either with the help of chemicals (dithiothreitol, DNase and other enzymes) or mechanically. When applying this technique, it is possible that intracellular granule contents from rupturing cells or cells trapped in the nets of plugs are liberated. Furthermore, compounds may be bound to mucus or other surfaces exposed during processing of the sample and thus lost to analysis. Thus, preanalytical issues are critical to the processing of sputum and should be evaluated and optimised prior to clinical studies.

Normal values for induced sputum cellular counts and composition have been established in both adults and children $[89,90]$. In CF patients, a limited number of studies have been performed involving a broad range of CF subjects (discussed further later). In particular, the assessment of induced sputum has proven helpful in studying the effect of antibiotic treatment $[20-22,86]$. The value of induced sputum in studying more subtle effects of anti-inflammatory therapies remains unclear as no study of anti-inflammatory drugs published to date using outcome measures obtained from induced sputum has convincingly demonstrated an effect. Recently, MAYERHAMBLETT et al. [91] reported the findings of a meta-analysis involving 269 CF patients from four US multicentric studies on the association between expectorated sputum biomarkers and lung function (FEV1). Among several biomarkers studied, HLE levels correlated with FEV1 both cross-sectionally and longitudinally, whereas IL-8 and other putative biomarkers showed no association with lung function in these patients, suggesting HLE may be useful as a biomarker in CF lung disease. In conclusion, both BALF and sputum are useful for the study of proteolytic activity/PEPA in CF lung disease, but the differences between the two techniques, especially with regard to the patient's age, sampling region and preanalytical issues, should be considered.

\section{CLINICAL SITUATIONS WITH DIFFERING PEPA}

CF lung disease is variable and compartmentalised in space and time, ranging from early lung disease without clinical symptoms to progressive lung disease with destruction of lung tissue and loss of pulmonary function. Given the broad range of CF lung disease, appropriate patient stratification is a prerequisite for clinical studies [23]. This section describes different stages of CF lung disease, with their typical scenarios and relevant implications of inhibition of HLE.

\section{Early lung disease with no established chronic infection and inflammation (clinically stable)}

This group comprises young patients, who usually exhibit a lung function within the normal range and show no clinical symptoms outside their exacerbations. BALF studies revealed that even CF infants aged $1 \mathrm{yr}$ exhibit increased neutrophil counts and HLE activity, depending upon the bacterial pathogens in their BALF $[92,93]$. Owing to the technical difficulties of inducing sputum in this population [86], BAL is required to study these patients over time. No long-term data are available regarding these patients with respect to their HLE status. Given the potential anti-inflammatory benefit of inhaled HLE inhibitors [94], the examination of such a population is of pivotal interest in examining whether or not HLE-directed therapeutics are able to prevent the establishment of persistent airway inflammation, improve clearance of pathogens within the airways, and, finally, decrease progression to chronic obstructive airways disease.

\section{Later lung disease with localised destruction and significant PEPA (clinically stable)}

The lung function of these subjects may well be within the normal range, although some compromise is likely, and chest CT scans can clearly depict the extent and sites of localised pulmonary destruction $[95,96]$. With inappropriate resolution of acute exacerbation, localised destructive and chronic lung disease is established in certain areas of the lung. Induced sputum obtained from subjects with this condition is likely to represent a mixture of healthy areas within the lung and areas of significant proteolytic activity and destruction. The later sputum fractions more precisely represent BALF composition [97]. The central question is whether treatment with inhaled protease inhibitors is able to overcome the excessive proteolysis in the area of localised destruction without adversely affecting other pulmonary areas in which antiproteolytic conditions pre-exist. In this context, the effect of inhaled $\alpha_{1}$ $\mathrm{AT}$ in conserving the integrity of the lungs over time might be of major importance in the microenvironment of localised destruction. The use of mixed induced sputum (with collection of material from the whole lung) is useful in the determination of whether or not overall control of elastolytic activity can be achieved. The analysis of sequential sputum fractions, conversely, may be helpful for resolution of the spatial distribution within the lungs [97]. However, this approach has not yet been used in studies of inhaled protease inhibitors and remains to be established in future investigations. 


\section{Late lung disease with general destruction and inflammatory activity (clinically stable)}

Patients with multilocalised lesions usually show a surplus of HLE in their sputum. Such patients typically exhibit chronic bacterial infection and reduced lung function. The degree of free HLE activity depends upon the overall severity of the lung disease. Previous studies of inhaled $\alpha_{1}$-AT in CF patients with progressive lung disease $[95,98]$ demonstrated that the HLE can be neutralised totally [98] or partially [95] depending upon the dose inhaled, the deposition mode and the method of obtaining airway fluids (BAL or sputum). Antiprotease use may be reasonable in this patient population in order to prevent further progression of pulmonary destruction.

\section{Acute exacerbation}

With acute disease exacerbation, protease activity is thought to be increased in CF airways. However, owing to difficulties in defining exacerbations precisely in $\mathrm{CF}$, as well as study logistics, well-designed clinical studies addressing the role of proteases in CF exacerbations are still lacking [11,99]. Thus the following critical questions remain unanswered. 1) Does antiHLE treatment reduce the duration of exacerbations, extent of damage, post-exacerbation sputum production and airway hyperreactivity? 2) Has co-treatment with antibiotics an impact upon the course of exacerbations? 3) Do antibiotics have an additional effect on protease activity or soluble/cellular targets of PEPA in CF airways, as demonstrated for colistin [100]? Potential harmful effects, such as the expansion of bacterial growth or enhancement of symptoms, should be observed very closely in this context.

\section{INHIBITION OF AIRWAY NEUTROPHIL ELASTASE}

In order to inhibit excess HLE activity, there are currently three classes of inhibitor available: 1) small synthetic chemical compounds; 2) semi-synthetic inhibitors obtained by modification of their natural counterparts; and 3) natural inhibitors of HLE (table 2).

\section{Synthetic inhibitors of neutrophil elastase}

Since there is increasing evidence that HLE-mediated tissue damage often occurs at the tight interface between neutrophil and substrate, $\alpha_{1}$-AT might have difficulty in accessing this

\begin{tabular}{lcc}
\hline TABLE 2 & $\begin{array}{l}\text { Classes of inhibitor of human neutrophil elastase } \\
(\mathrm{hNE})\end{array}$ & Natural \\
\hline Synthetic & Semi-synthetic ${ }^{\#}$ & $\boldsymbol{\alpha}_{1}$-antitrypsin \\
\hline Sivelestat & $\begin{array}{c}\text { EPI-hNE-4 } \\
(\text { inter- } \alpha \text {-inhibitor }) \\
\text { SUPG-032 } \\
\left(\boldsymbol{\alpha}_{1} \text {-antichymotrypsin }\right) \\
\text { SLAPI } \\
\left(\alpha_{1} \text {-antitrypsin and SLPI) }\right.\end{array}$ & SLPI \\
& Pre-elafin \\
& $\begin{array}{c}\text { Monocyte/neutrophil } \\
\text { elastase inhibitor }\end{array}$ \\
\hline
\end{tabular}

EPI: engineered protein inhibitor; SLAPI: $\alpha_{1}$-antitrypsin-secretory leukocyte protease inhibitor (SLPI) fusion protein. ${ }^{*}$ : obtained by modification of the natural mother compounds shown in parentheses. area due to its large size (52 kDa) and negative charge [101]. This and other pharmacological and economic issues suggested the development of synthetic and semi-synthetic serine protease inhibitors (serpins), as summarised later. A large number of synthetic chemical compounds have been synthesised and partially tested for inhibition of HLE [102]. In theory, these low-molecular weight inhibitors might be superior to $\alpha_{1^{-}}$ AT on the basis of their size, resulting in better accessibility to narrow proteolytic sites within the CF lung [103-105]. However, due to unexpected toxicity or further relevant issues, none of the synthetic inhibitors have yet been introduced into clinical practice. Both peptide (such as ICI 200355; ICI Americas, Wilmington, DE, USA) and nonpeptide HLE inhibitors (ONO-5046; Ono Pharmaceutical Co. Ltd, Osaka, Japan) have been developed. Sivelestat, for instance, (ONO5046/Elaspol) is a reversible selective inhibitor of HLE, which was initially launched in Japan. A phase 2 clinical study in patients with acute lung injury was suspended due to unfavourable effects of the compound. Midesteine (MR-889; Medea Research, Milan, Italy) represents another reversible low-affinity inhibitor of HLE, which was found to reduce mucus viscosity due to its interaction with thiol groups. It appears safe and is undergoing clinical evaluation for chronic obstructive lung disease. Specifically for CF, DMP-777 has been tested in phase 2 studies; however, its development was discontinued by the company. All other developments are in much earlier phases [106], and no results have yet been published.

\section{Semi-synthetic inhibitors}

Semi-synthetic inhibitors are usually obtained by chemical modification of natural human protease inhibitors. For example, engineered protein inhibitor of human neutrophil elastase (EPI-hNE-4) is derived from the Kunitz-type domain of inter- $\alpha$-inhibitor $[107,108]$, which is a natural inhibitor of HLE normally present in plasma. EPI-hNE-4 is a 56-aminoacid-long fragment with a very low equilibrium dissociation constant of $4 \mathrm{pM}$ for HLE, and has the advantage that it is derived from humans and is resistant against proteolysis and oxidation [107]. Studies in animals as well as using sputum from CF children, revealed successful inhibition of HLE and a decrease in neutrophil migration [109]. EPI-hNE-4 is currently being tested in phase 2 studies in patients with CF. SUPG-032 represents a nonglycosylated recombinant modified human $\alpha_{1^{-}}$ antichymotrypsin in which six reactive-site amino acids have been replaced by those of $\alpha_{1}-\mathrm{AT}$, and is active against HLE, cathepsin $\mathrm{G}$ and protease 3. The hybrid compound also inhibits superoxide generation by neutrophils. Unfortunately, its further development was suspended. Finally, mention should be made of a fusion protein containing both $\alpha_{1}$-AT and secretory leukocyte protease inhibitor (SLPI) activity, the current development status of which is unknown.

\section{Natural inhibitors}

Natural inhibitors of HLE comprise $\alpha_{1}$-AT, monocyte/neutrophil elastase inhibitor (MNEI) and serpins, such as SLPI and elafin/pre-elafin. Studies with $\alpha_{1}$-AT are addressed separately in the section below. SLPI, a 12-kDa highly-cationic hydrophobic nonglycosylated single-chain protein, is produced in the central airways by serous glandular cells and in the lower respiratory tract by Clara cells and goblet cells, and appears to 
be an efficient inhibitor of HLE activity in the airways. SLPI and $\alpha_{1}$-AT are regarded as the major defence proteins against excessive HLE, providing $10-50 \%$ of the total HLE-inhibitory capacity $[110,111]$. Since the reactivity of SLPI differs from that of $\alpha_{1}$-AT, both antiproteases may act complementarily in vivo. MCELVANEY et al. [112] studied the effect of 1 week's inhalation of recombinant human SLPI (100 mg twice daily) in 16 adult patients with CF. As assessed by BAL, the number of neutrophils and levels of IL- 8 were reduced and HLE activity was decreased for $>12 \mathrm{~h}$. However, when only $50 \mathrm{mg}$ were used for 2 weeks, no such effects could be observed, clearly showing dose dependency. Elafin, a 6-kDa peptide similar to SLPI, is a specific elastase inhibitor, which is suggested to contribute up to $20 \%$ of the anti-HLE capacity of the lung in vivo $[113,114]$. Both SLPI and elafin are upregulated by proinflammatory cytokines in airway epithelial cells $[115,116]$, but may act anti-inflammatorily since both were found to inhibit nuclear factor- $\kappa \mathrm{B}$ activity and IL-8 and monocyte chemoattractant protein-1 production [117, 118]. To the best of the present authors' knowledge, pre-elafin and MNEI have not as yet been studied in patients with CF. However, animal data show a substantial reduction in $P$. aeruginosa counts in a mouse model of chronic infection after treatment with MNEI for up to 7 days [119]. Further clinical studies using natural inhibitors of HLE need to be conducted in CF patients in order to precisely evaluate their potency, beneficial and harmful effects, and usefulness in clinical settings.

Besides antiproteases, antibiotics were found to differentially affect proteases. Macrolide antibiotics were found to show HLE-inhibitory activity, whereas colistin increased HLE activity in vitro $[100,120]$.

\section{INHIBITION OF FREE ELASTASE BY INHALED $\alpha_{1}$-AT IN PATIENTS WITH CF}

$\alpha_{1}-\mathrm{AT}$ is a $52-\mathrm{kDa}$ glycoprotein that is secreted mainly by hepatocytes, alveolar macrophages and neutrophils and acts as a potent serine protease inhibitor [121]. The interaction of $\alpha_{1}$ AT with HLE results in a rapid and irreversible inactivation of the protease. Serum concentrations in healthy individuals range $20-60 \mu \mathrm{M} . \alpha_{1}-\mathrm{AT}$, released by the liver, diffuses into the lung. Although levels in the lung are lower $(\sim 2-7 \mu \mathrm{M}), \alpha_{1}$-AT is considered to contribute $>90 \%$ of the antiproteolytic capacity present in the pulmonary compartment [122]. When considering $\alpha_{1}$-AT as a therapeutic agent, the source may be human serum or recombinant protein expressed in other systems, such as micro-organisms or transgenic animals [123]. A commercial $\alpha_{1}$-AT preparation is available from pooled human plasma (Prolastin; Talecris Biotherapeutics, Research Triangle Park, NC, USA). Prolastin is well tolerated and effective in vivo, but the purity of the preparation is only $\sim 60 \%$ [124]. Novel $\alpha_{1}$-AT replacement preparations, such as Zemaira or Aralast, have shown equivalency with Prolastin in augmenting $\alpha_{1}$-AT serum and alveolar epithelial levels and provide greater purity than conventional preparations (Zemaira $>$ Aralast $>$ Prolastin) [124-126]. However, clinical data on the use of these preparations in $\mathrm{CF}$ patients are unavailable to date.

Intravenous $\alpha_{1}$-AT application was initially used in individuals with $\alpha_{1}$-AT deficiency, has been reported to be safe and well tolerated [127], and is currently recommended for individuals with severe hereditary (PiZZ/null) $\alpha_{1}$-AT deficiency [128, 129]. However, in CF airways, the amount of free proteases present is very high (mostly $>10 \mu \mathrm{M}$ and sometimes even up to $100 \mu \mathrm{M})$ and the affected sites in CF lungs may be barely accessible to $\alpha_{1}$-AT. $\alpha_{1}$-AT administered via i.v. was considered for treating CF patients. However, preliminary studies showed that large doses and repetitive administration would be required to achieve beneficial long-term effects [130]. Accordingly, aerosolised $\alpha_{1}$-AT has gained increasing attention since: 1) the direct site of disease is targeted, with higher pulmonary concentrations achieved; 2) systemic side-effects are less probable; 3 ) smaller amounts of $\alpha_{1}$-AT are required; and 4) no i.v. access is required.

Transgenic technology enables the high-volume production of active recombinant proteins, which is cost-efficient compared with purified human serum $\alpha_{1}$-AT. PPL Therapeutics (Roslin, UK) have developed transgenic sheep that produce in their milk human $\alpha_{1}$-AT that is almost identical to human-derived $\alpha_{1}$-AT, with the exception of some of the side-chain sugars [131]. Since recombinant $\alpha_{1}$-AT has a short half-life, i.v. administration is precluded but aerosol administration is feasible [132]. A pilot study in CF patients using recombinant $\alpha_{1}$-AT derived from transgenic sheep showed no allergic effects up to doses of $500 \mathrm{mg}$ recombinant $\alpha_{1}$-AT $\cdot$ day $^{-1}$ [133]. Nevertheless, use of recombinant $\alpha_{1}$-AT may have the problem of antibody responses to traces of inhaled nonhuman proteins and may lead to anaphylactic reactions [134].

Tables 3 and 4 summarise published studies using BAL (table 3) and sputum (table 4) to assess the effect of inhaled $\alpha_{1}$-AT in patients with CF lung disease.

A phase 1 study evaluated the biochemical effect of $\alpha_{1}$-AT inhalation in CF patients and has provided important insight into the potential effects of aerosolised $\alpha_{1}$-AT in CF lung disease [98]. Twelve adult subjects with CF inhaled 100$200 \mathrm{mg}\left(1.5-3.0 \mathrm{mg} \cdot \mathrm{kg}\right.$ body weight $\left.{ }^{-1}\right) \alpha_{1}$-AT twice daily for 1 week. The estimated efficacy of the nebuliser to deliver $\alpha_{1}$ AT into the lungs was $\sim 10-20 \%$, resulting in pulmonary deposition of $\sim 10-40 \mathrm{mg}$. Before inhalation, all subjects had their BALF HLE activity measured. If the epithelial lining fluid concentration of $\alpha_{1}$-AT was increased to a level of $>8 \mu \mathrm{M}$, all free HLE was blocked. Interestingly, post-treatment BALF did not inhibit neutrophil killing of $P$. aeruginosa in vitro, as was found using pretreatment BALF, suggesting that HLE efficiently impairs antibacterial neutrophil functions in vivo. This study in CF patients with an FEV1 of $>60 \%$ of the predicted value clearly demonstrated free HLE in the alveolar compartment, which was neutralised dose-dependently and reached free anti-HLE capacity in some cases. In another smaller study, treatment with $\alpha_{1}$-AT in the lower dose range led to reduced levels of total protein, numbers and amounts of proteins with a molecular weight of $<20 \mathrm{kDa}$, and degradation products of SP-A [137]. In the latter study, no effect of $\alpha_{1}$-AT on surfactant convertase, an alveolar enzyme hypothesised to be inhibited by serine protease inhibitors, was noted [138]. In healthy adults, the $\alpha_{1}$-AT half-life is $69.2 \mathrm{~h}$ and the half-life of antielastolytic capacity is $53.2 \mathrm{~h}$, suggesting that once daily dosing may be appropriate. However, the functional half-life under specific conditions, such as $\mathrm{CF}$, may be different and remains to be determined. 
In the only randomised placebo-controlled $\mathrm{CF}$ trial using induced sputum to assess the effect of different doses of inhaled $\alpha_{1}$-AT $(125,250$ and $500 \mathrm{mg}$ ), levels of myeloperoxidase, a surrogate for neutrophil activity, were reduced after $\alpha_{1}$-AT treatment, but only in the group receiving the highest dosage of $\alpha_{1}$-AT (500 mg) [133]. Similarly, levels of taurine, also a surrogate for neutrophils, were marginally reduced [139]. In line with this finding, it was found that the number of neutrophils, as well as pro-inflammatory cytokine levels, was reduced after $\alpha_{1}$-AT inhalation [94]. Interestingly, in these studies, the HLE activity of sputum was not [133, 139], or was only partially [94], reduced. Another study involving 22 adult CF patients was published in abstract form only by BERGER $e t$ al. [136], showing a decrease in HLE levels but no changes in IL-8 levels and numbers of neutrophils upon aerosolised $\alpha_{1}$-AT treatment. What are the reasons for this discrepancy between sputum and BAL $\alpha_{1}$-AT studies? First, sputum and BAL sample different areas of the lungs. The more peripheral region sampled by BAL is expected to exhibit lower inflammatory activity and bacterial load [84]. CF lung disease is almost completely excluded from the alveolar space, and, even in severely damaged explanted lungs obtained after lung transplantation, only few inflammatory cells are observed in the alveoli [140]. Secondly, during preparation of BALF supernatant, the mucus recovered by lavage, containing trapped leukocytes and other elements attached to it, is often removed during filtration. In contrast, during preparation of sputum, cellular debris and apoptotic leukocytes may be included in the analysis. Finally, the different methods used to obtain sputum supernatant should be considered. When a sol phase is prepared, undetermined intra- and extracellular components can be released into the supernatant. This cannot be readily compared to a cell-free supernatant prepared by mechanical, enzymatic or biochemical means.

In an attempt to define the optimal regions within the lungs of CF patients for delivery of $\alpha_{1}-\mathrm{AT}$, preferential peripheral (alveolar) deposition was compared to more central (bronchial) deposition [94]. No differences in any outcome parameter were found between the two deposition methods. In combining both of these groups, the previously mentioned study showed that inhalation of $\alpha_{1}$-AT increased $\alpha_{1}$-AT levels and decreased levels of HLE activity, percentages of neutrophils, levels of pro-inflammatory cytokines and colony counts of P. aeruginosa. Lung function was not affected by $\alpha_{1}$-AT inhalation, which may be due to the relatively short treatment period. Drawbacks of antiprotease therapy are that aerosolised antiproteases, as with most other drugs, can barely be deposited in the poorly ventilated areas of the lung that need treatment most. In addition, the pharmacokinetic and dynamic characteristics of a complex environment such as the CF lung are hard to establish. Thus, the challenge remains to efficiently deposit $\alpha_{1}$-AT at the site of CF lung disease. It is, therefore, critical that the delivery system is optimised for maximal drug delivery over a brief period of time with minimal aerosol loss. This can be achieved by combining an efficient nebuliser, which generates the aerosol, with a device that guarantees an optimised breathing pattern. The AKITA (electronically regulated device for the controlled inhalation of therapeutic aerosols) device, programmed for the individual breathing pattern using a smart card, represents such a system. Using 
TABLE 4 Sputum studies of inhaled aerolised $\alpha_{1}$-antitrypsin ${ }^{\#}\left(\alpha_{1}-\right.$ AT) in patients with cystic fibrosis (CF) and healthy volunteers

\begin{tabular}{|c|c|c|c|c|c|c|c|c|c|c|c|}
\hline \multirow{2}{*}{\multicolumn{2}{|c|}{ Subjects $n$}} & \multirow[t]{2}{*}{ Nebuliser } & \multicolumn{2}{|c|}{$\alpha_{1}$-AT aerosol } & \multicolumn{2}{|r|}{ Sample } & \multicolumn{2}{|c|}{$\begin{array}{l}\text { Elastase } \\
\mu \mathrm{g} \cdot \mathrm{mL}^{-1}\end{array}$} & \multicolumn{2}{|c|}{$\begin{array}{c}\alpha_{1}-\mathrm{AT} \\
\mu \mathrm{g} \cdot \mathrm{mL}^{-1}\end{array}$} & \multirow[t]{2}{*}{ [Ref.] } \\
\hline & & & $\begin{array}{c}\text { Dose in } \\
\text { nebuliser } \mathrm{mg}\end{array}$ & $\begin{array}{c}\text { DD to } \\
\text { lungs }{ }^{\circ} \mathrm{mg} \\
\text { (\% dose) }\end{array}$ & Type & $\begin{array}{c}\text { Time after } \\
\text { last inhalation } \mathrm{h}\end{array}$ & Before & After & Before & After & \\
\hline \multirow[t]{4}{*}{ CF } & 39 & Pari LC Star & $\begin{array}{l}125-500 \text { q.d. } \\
\text { for } 4 \text { weeks }\end{array}$ & Placebo & S, SP & 24 & $2.6 \pm 3.8$ & & $N G$ & $N G$ & [133] \\
\hline & & & & $25(20)$ & & & $0.8 \pm 1.7$ & $p=0.21$ & & & \\
\hline & & & & $50(20)$ & & & $2.8 \pm 4.9$ & $p=0.09$ & & & \\
\hline & & & & $100(20)$ & & & $0.7 \pm 1.9$ & $p=0.31$ & & & \\
\hline
\end{tabular}

AKITA is manufactured by Inamed, Gemünden, Germany. Pari LC Plus and Pari LC Star are manufactured by Pari, Starnberg, Germany. DD: delivered dose; IS: induced sputum; S: sputum; SP: sol phase; NG: not given; AKITA: electronically regulated device for the controlled inhalation of therapeutic aerosols. "\#: prolastin; ": per inhalation; + : AKITA used so as to guarantee deposition of $25 \mathrm{mg} \alpha_{1}-\mathrm{AT}$ in the lungs; ${ }^{\text {s }}$ : conversion from $5.2 \pm 0.9 \mu \mathrm{M}$ given in original; ${ }^{f}$ : conversion from $5.0 \pm 1.2 \mu \mathrm{M}$ given in original; \#\#: conversion from $2.4 \pm 0.4 \mu \mathrm{M}$ given in original; ${ }^{~}{ }^{\circ}$ : conversion from $8.1 \pm 1.9 \mu \mathrm{M}$ given in original. $1 \mu \mathrm{M}=52 \mu \mathrm{g} \cdot \mathrm{mL}^{-1} \mathrm{and} 1 \mathrm{mg}=0.019 \mu \mathrm{mol} \alpha_{1}-\mathrm{AT}$; $1 \mu \mathrm{M}=30 \mu \mathrm{g} \cdot \mathrm{mL}^{-1}$ and $1 \mathrm{mg}=0.033 \mu \mathrm{mol}$ human leukocyte elastase (assuming all enzyme is active).

this approach, $\sim 85 \%$ of the aerosol can be delivered into the lungs [94]. This device is superior for the targeting and delivery of even relatively large amounts of aerosols into the lungs compared to previous systems. Automatic monitoring of compliance helps to define adherence to treatment.

\section{IMPLICATIONS FOR CLINICAL TRIALS}

Given the numerous targets of PEPA in CF lung disease, many potential outcome variables for clinical phase 1 and $2 a$ studies of antiproteolytic treatment can be envisioned. These approaches will permit greater insight into the pathophysiology of CF lung disease. For future clinical studies of HLE inhibition in CF patients, however, it is important that the relevant target populations are clearly defined and stratified. Success in these trials will only be achieved by: 1) selection of representative study populations, 2) well-designed primary and secondary outcome parameters, 3) thoroughly characterised protocols for sample preparation, and 4) on-site training for compliance with these procedures. Finally, batch analysis of all variables for which storage is possible in an experienced central laboratory is essential. For phase $2 b$ and 3 studies, outcome variables such as FEV1 and rate and time to exacerbation are appropriate; additional analysis of surrogate markers, e.g. cytokine analyses, in a study subcentre can be helpful in the interpretation of the results. Large studies of inhaled $\alpha_{1}$-AT or other protease inhibitors are essential to the systemic evaluation of the effect of HLE inhibition as a therapeutic approach in CF lung disease.

\section{SUMMARY}

Inhibition of airway neutrophil elastase represents a causative approach to limiting the self-destructive process of neutrophilderived protease activity in cystic fibrosis lung disease. Despite several attempts designed to achieve this goal, clinically useful concepts have only just started to evolve. $\alpha_{1}$-Antitrypsin, the natural inhibitor of free elastase, has been employed in a few clinical studies and has yielded promising, but not yet convincing, results. Representative study populations, elaborated protocols for sample preparation, methodological accuracy and relevant end-points are warranted in order to further validate the usefulness of elastase inhibition in cystic fibrosis lung disease.

\section{REFERENCES}

1 Davis PB, Drumm M, Konstan M. Cystic fibrosis. Am J Respir Crit Care Med 1996; 154: 1229-1256.

2 Chmiel JF, Konstan MW. Inflammation and anti-inflammatory therapies for cystic fibrosis. Clin Chest Med 2007; 28: 331-346.

3 Gentzsch M, Choudhury A, Chang XB, Pagano RE, Riordan JR. Misassembled mutant $\triangle$ F508 CFTR in the distal secretory pathway alters cellular lipid trafficking. J Cell Sci 2007; 120: 447-455.

4 Konstan MW, Byard PJ, Hoppel CL, Davis PB. Effect of high-dose ibuprofen in patients with cystic fibrosis. New Engl J Med 1995; 332: 848-854.

5 Konstan MW, Krenicky JE, Finney MR, et al. Effect of ibuprofen on neutrophil migration in vivo in cystic fibrosis and healthy subjects. J Pharmacol Exp Ther 2003; 306: 1086-1091.

6 Konstan MW, Schluchter MD, Xue W, Davis PB. Clinical use of ibuprofen is associated with slower FEV1 decline in children with cystic fibrosis. Am J Respir Crit Care Med 2007; 176: 1084-1089.

7 Paul K, Rietschel E, Ballmann M, et al. Effect of treatment with dornase alpha on airway inflammation in cystic 
fibrosis patients. Am J Respir Crit Care Med 2004; 169: 719-725.

8 Balfour-Lynn IM, Lees B, Hall P, et al. Multicenter randomized controlled trial of withdrawal of inhaled corticosteroids in cystic fibrosis. Am J Respir Crit Care Med 2006; 173: 1356-1362.

9 Konstan MW, Doring G, Lands LC. Results of a phase II clinical trial of BIIL 284 BS (an $\mathrm{LTB}_{4}$ receptor antagonist) for the treatment of CF lung disease. Ped Pulm 2005; 40: Suppl. 28, 125-126.

10 Abbott J, Hart A. Measuring and reporting quality of life outcomes in clinical trials in cystic fibrosis: a critical review. Health Qual Life Outcomes 2005; 24: 19.

11 Rosenfeld M, Emerson J, Williams-Warren J, et al. Defining a pulmonary exacerbation in cystic fibrosis. J Pediatr 2001; 139: 359-365.

12 Aurora P, Gustafsson P, Bush A, et al. Multiple breath inert gas washout as a measure of ventilation distribution in children with cystic fibrosis. Thorax 2004; 59: 1068-1073.

13 de Jong PA, Nakano Y, Lequin MH, et al. Progressive damage on high resolution computed tomography despite stable lung function in cystic fibrosis. Eur Respir J 2004; 23: 93-97.

14 Brand $\mathrm{P}$, Meyer T, Häussermann S, et al. Optimum peripheral drug deposition in patients with cystic fibrosis. J Aerosol Med 2005; 18: 45-54.

15 Armstrong DS, Grimwood K, Carlin JB, et al. Lower airway inflammation in infants and young children with cystic fibrosis. Am J Respir Crit Care Med 1997; 156: 1197-1204.

16 Sagel SD, Sontag MK, Wagener JS, Kapsner RK, Osberg I, Accurso FJ. Induced sputum inflammatory measures correlate with lung function in children with cystic fibrosis. J Pediatr 2002; 141: 811-817.

17 Prasad SA, Randall SD, Balfour-Lynn IM. Fifteen-count breathlessness score: an objective measure for children. Pediatr Pulmonol 2000; 30: 56-62.

18 Ramsey BW, Astley S, Aitken M, et al. Efficacy and safety of short-term administration of aerosolized recombinant human deoxyribonuclease in patients with cystic fibrosis. Am Rev Respir Dis 1993; 148: 145-151.

19 Saiman L, Siegel J. Infection control in cystic fibrosis. Clin Microbiol Rev 2004; 17: 57-71.

20 Downey DG, Brockbank S, Martin SL, Ennis M, Elborn JS. The effect of treatment of cystic fibrosis pulmonary exacerbations on airways and systemic inflammation. Pediatr Pulmonol 2007; 42: 729-735.

21 Ordonez CL, Henig NR, Mayer-Hamblett N, et al. Inflammatory and microbiologic markers in induced sputum after intravenous antibiotics in cystic fibrosis. Am J Respir Crit Care Med 2003; 168: 1471-1475.

22 Downey DG, Martin SL, Dempster M, et al. The relationship of clinical and inflammatory markers to outcome in stable patients with cystic fibrosis. Pediatr Pulmonol 2007; 42: 216-220.

23 Doring G, Elborn JS, Johannesson M, et al. Clinical trials in cystic fibrosis. J Cyst Fibros 2007; 6: 85-99.

24 Bonfield TL. Inflammatory cytokines in cystic fibrosis lungs. Am J Respir Crit Care Med 1995; 152: 2111-2118.

25 Belaaouaj A, McCarthy R, Baumann M, et al. Mice lacking neutrophil elastase reveal impaired host defense against Gram negative bacterial sepsis. Nat Med 1998; 4: 615-618.
26 Belaaouaj A. Neutrophil elastase-mediated killing of bacteria: lessons from targeted mutagenesis. Microbes Infect 2002; 4: 1259-1264.

27 Brinkmann V, Reichard U, Goosmann C, et al. Neutrophil extracellular traps kill bacteria. Science 2004; 303: 1532-1535.

28 Brinkmann V, Zychlinsky A. Beneficial suicide: why neutrophils die to make NETs. Nat Rev Microbiol 2007; 5 577-582.

29 Fuchs TA, Abed U, Goosmann C, et al. Novel cell death program leads to neutrophil extracellular traps. J Cell Biol 2007; 176: 231-241.

30 Urban CF, Reichard U, Brinkmann V, Zychlinsky A. Neutrophil extracellular traps capture and kill Candida albicans yeast and hyphal forms. Cell Microbiol 2006; 8: 668-676.

31 Janoff A. Elastases and emphysema. Current assessment of the protease-antiprotease hypothesis. Am Rev Respir Dis 1985; 132: 417-433.

32 Fujita J, Nelson NL, Daughton DM, et al. Evaluation of elastase and antielastase balance in patients with chronic bronchitis and pulmonary emphysema. Am Rev Respir Dis 1990; 142: 57-62.

33 Birrer P, McElvaney N, Rüderberg A, et al. Proteaseantiprotease imbalance in the lungs of children with cystic fibrosis. Am J Respir Crit Care Med 1994; 150: 207-213.

34 Suter S, Schaad UB, Tegner H, Ohlsson K Desgrandchamps D, Waldvogel FA. Levels of free granulocyte elastase in bronchial secretions from patients with cystic fibrosis: effect of antimicrobial treatment against Pseudomonas aeruginosa. J Infect Dis 1986; 153: 902-909.

35 Suter S. Imbalance between polymorphonuclear leukocyte proteases and antiproteases in chronic pyogenic infections and its relation to the proteolysis of complement component C3. Complement 1986; 3: 1-24.

36 O'Connor CM, Gaffney K, Keane J, et al. $\alpha_{1}$-Proteinase inhibitor, elastase activity, and lung disease severity in cystic fibrosis. Am Rev Respir Dis 1993; 148: 1665-1670.

37 Döring G. The role of neutrophil elastase in chronic inflammation. Am J Respir Crit Care Med 1994; 150: 114-117.

38 Rees DD, Brain JD, Wohl ME, Humes JL, Mumford RA. Inhibition of neutrophil elastase in CF sputum by L658,758. J Pharmacol Exp Ther 1997; 283: 1201-1206.

39 Janoff A. Mediators of tissue damage in human polymorphonuclear neutrophils. Ser Haematol 1970; 3: 96-130.

40 Janoff A. Human granulocyte elastase. Further delineation of its role in connective tissue damage. Am J Pathol 1972; 68: 579-592.

41 Janoff A. Neutrophil proteases in inflammation. Annu Rev Med 1972; 23: 177-190.

42 Janoff A. Proteases and lung injury. A state-of-the-art minireview. Chest 1983; 83: Suppl. 5, 54S-58S.

43 Janoff A. Elastase in tissue injury. Annu Rev Med 1985; 36: 207-216.

44 Okada Y, Watanabe S, Nakanishi I, et al. Inactivation of tissue inhibitor of metalloproteinases by neutrophil elastase and other serine proteinases. FEBS Lett 1988; 229: 157-160.

45 Döring G, Goldstein W, Botzenhart K, et al. Elastase from polymorphonuclear leucocytes: a regulatory enzyme in immune complex disease. Clin Exp Immunol 1986; 597-605. 
46 Kelly E, Greene CM, McElvaney NG. Targeting neutrophil elastase in cystic fibrosis. Expert Opin Ther Targets 2008; 12: 145-157.

47 Lee WL, Downey GP. Leukocyte elastase: physiological functions and role in acute lung injury. Am J Respir Crit Care Med 2001; 164: 896-904.

48 Stockley RA. Proteases and antiproteases. Novartis Found Symp 2001; 234: 189-199.

49 Khan T, Wagener J, Bost T, Martinez J, Accurso F, Riches D. Early pulmonary inflammation in infants with cystic fibrosis. Am J Respir Crit Care Med 1995; 151: 1075-1082.

50 Taggart CC, Greene CM, Carroll TP, O’Neill SJ, McElvaney NG. Elastolytic proteases. Inflammation resolution and dysregulation in chronic infective lung disease. Am J Respir Crit Care Med 2005; 171: 1070-1076.

51 Tosi MF, Zakem H, Berger M. Neutrophil elastase cleaves C3bi on opsonized pseudomonas as well as CR1 on neutrophils to create a functionally important opsonin receptor mismatch. J Clin Invest 1990; 86: 300-308.

52 Fick RB, Naegel GP, Squier SU, Wood RE, Gee JBL, Reynolds HY. Proteins of the cystic fibrosis respiratory tract. Fragmented immunoglobulin G opsonic antibody causing defective opsonophagocytosis. J Clin Invest 1984; 74: 236-248.

53 Griese M, Wiesener A, Lottspeich F, von Bredow C. Limited proteolysis of surfactant protein D causes a loss of its calcium-dependent lectin functions. Biochim Biophys Acta 2003; 1638: 157-163.

54 von Bredow C, Wiesener A, Griese M. Proteolysis of surfactant protein D by cystic fibrosis relevant proteases. Lung 2003; 181: 79-88.

55 Hirche TO, Crouch EC, Espinola M, et al. Neutrophil serine proteinases inactivate surfactant protein $\mathrm{D}$ by cleaving within a conserved subregion of the carbohydrate recognition domain. J Biol Chem 2004; 279: 27688-27698.

56 Alcorn JF, Wright JR. Degradation of pulmonary surfactant protein $\mathrm{D}$ by Pseudomonas aeruginosa elastase abrogates innate immune function. J Biol Chem 2004; 279: 30871-30879.

57 Lopez-boado YS, Espinola M, Bahr S, Belaaouaj A. Neutrophil serine proteinases cleave bacterial flagellin, abrogating its host response-inducing activity. J Immunol 2004; 172: 509-515.

58 Tsao F, Meyer K, Chen X, Rosenthal NS, Hu J. Degradation of annexin I in bronchoalveolar lavage fluid from patients with cystic fibrosis. Am J Respir Cell Mol Biol 1998; 18: 120-128.

59 Shamamian P, Schwartz JD, Pocock BJZ, et al. Activation of progelatinase A (MMP-2) by neutrophil elastase, cathepsin G, and proteinase-3: a role for inflammatory cells in tumor invasion and angiogenesis. J Cell Physiol 2001; 189: 197-206.

60 Geraghty P, Rogan MP, Greene CM, et al. Neutrophil elastase up-regulates cathepsin $\mathrm{B}$ and matrix metalloprotease-2 expression. J Immunol 2007; 9: 5871-5878.

61 Ferry G, Lonchampt M, Pennel L, deNanteuil G, Canet E, Tucker GC. Activation of MMP-9 by neutrophil elastase in an in vivo model of acute lung injury. FEBS Lett 1997; 402: 111-115.

62 Gaggar A, Li Y, Weathington N, et al. Matrix metalloprotease-9 dysregulation in lower airway secretions of cystic fibrosis patients. Am J Physiol Lung Cell Mol Physiol 2007; 293: L96-L104.

63 Ratjen F, Hartog CM, Paul K, Wermelt J, Braun J. Matrix metalloproteases in BAL fluid of patients with cystic fibrosis and their modulation by treatment with dornase alpha. Thorax 2002; 57: 930-934.

$64 \mathrm{Yu}$ Q, Stamenkovic I. Cell surface-localized matrix metalloproteinase- 9 proteolytically activates TGF- $\beta$ and promotes tumor invasion and angiogenesis. Genes Dev 2000; 14: 163-176.

65 Weathington NM, van Houwelingen AH, Noerager BD, et al. A novel peptide CXCR ligand derived from extracellular matrix degradation during airway inflammation. Nat Med 2006; 12: 317-323.

66 Sommerhoff CP, Nadel JA, Basbaum CB, Caughey GH. Neutrophil elastase and cathepsin $G$ stimulate secretion from cultured bovine airway gland serous cells. J Clin Invest 1990; 85: 682-689.

67 Fahy JV, Schuster A, Ueki I, Boushey HA, Nadel JA. Mucus hypersecretion in bronchiectasis. The role of neutrophil proteases. Am Rev Respir Dis 1992; 146: 14301433.

68 Fadok VA, Bratton DL, Henson PM. Phagocyte receptors for apoptotic cells: recognition, uptake, and consequences. J Clin Invest 2001; 108: 957-962.

69 Fadok VA, Bratton DL, Rose DM, Pearson A, Ezekewitz RAB, Henson PM. A receptor for phosphatidylserine-specific clearance of apoptotic cells. Nature 2000; 405: 85-90.

70 Vandivier RW, Fadok VA, Hoffmann PR, et al. Elastasemediated phosphatidylserine receptor cleavage impairs apoptotic cell clearance in cystic fibrosis and bronchiectasis. J Clin Invest 2002; 109: 661-670.

71 Huynh MLN, Fadok VA, Henson PM. Phosphatidylserinedependent ingestion of apoptotic cells promotes TGF- $\beta 1$ secretion and the resolution of inflammation. J Clin Invest 2002; 109: 41-50.

72 Walsh DE, Greene CM, Carroll TP, et al. Interleukin-8 upregulation by neutrophil elastase is mediated by MyD88/ IRAK/TRAF-6 in human bronchial epithelium. I Biol Chem 2001; 276: 35494-35499.

73 Hubbard RC, Fells G, Gadek J, Pacholok S, Humes J, Crystal RG. Neutrophil accumulation in the lung in alpha-1-antitrypsin deficiency. Spontaneous release of leukotriene- $\mathrm{B}_{4}$ by alveolar macrophages. I Clin Invest 1991; 88: 891-897.

74 Berger $M$, Sorensen RU, Tosi MF, Dearborn DG, Döring G. Complement receptor expression on neutrophils at an inflammatory site, the Pseudomonas-infected lung in cystic fibrosis. J Clin Invest 1989; 84: 1302-1313.

75 Porteu F, Brockhaus M, Wallach D, Engelmann H, Nathan CF. Human neutrophil elastase releases a ligandbinding fragment from the 75-kDa tumor-necrosis-factor (TNF) receptor. Comparison with the proteolytic activity responsible for shedding of TNF receptors from stimulated neutrophils. J Biol Chem 1991; 266: 18846-18853.

76 Remold-O'Donnell E, Parent D. Specific sensitivity of CD43 to neutrophil elastase. Blood 1995; 86: 2395-2402.

77 Hartl D, Latzin P, Hordijk P, et al. Cleavage of CXCR1 on neutrophils disables bacterial killing in cystic fibrosis lung disease. Nat Med 2007; 13: 1423-1430. 
78 Döring G, Frank F, Boudier C, Herbert S, Fleischer B, Bellon G. Cleavage of lymphocyte surface antigens CD2, CD4 and CD8 by polymorphonuclear leukocyte elastase and cathepsin $\mathrm{G}$ in patients with cystic fibrosis. J Immunol 1995; 154: 4842-4850.

79 Nemoto E, Sugawara S, Tada H, Takada H, Shimauchi H, Horiuchi $H$. Cleavage of CD14 on human gingival fibroblasts cocultured with activated neutrophils is mediated by human leukocyte elastase resulting in down-regulation of lipopolysaccharide-induced IL-8 production. J Immunol 2000; 165: 5807-5813.

80 Le Barillec K, Si-Tahar M, Balloy V, Chignard M. Proteolysis of monocyte CD14 by human leukocyte elastase inhibits lipopolysaccharide-mediated cell activation. J Clin Invest 1999; 103: 1039-1046.

81 Berger M. Inflammatory mediators in cystic fibrosis lung disease. Allergy Asthma Proc 2002; 23: 19-25.

82 Baggiolini M, Clark-Lewis I. Interleukin-8, a chemotactic and inflammatory cytokine. FEBS Lett 1992; 307: 97-101.

83 Hilliard JB, Konstan MW, Davis PB. Inflammatory mediators in CF patients. Methods Mol Med 2002; 70: 409-431.

84 Ratjen F, Rietschel E, Griese M, et al. Fractional analysis of bronchoalveolar lavage fluid cytology in cystic fibrosis patients with normal lung function. Eur Respir J 2000; 15 : 141-145.

85 Colombo C, Costantini D, Rocchi A, et al. Cytokine levels in sputum of cystic fibrosis patients before and after antibiotic therapy. Pediatr Pulmonol 2005; 40: 15-21.

86 Sagel SD, Chmiel JF, Konstan MW. Sputum biomarkers of inflammation in cystic fibrosis lung disease. Proc Am Thorac Soc 2007; 4: 406-417.

87 Mussaffi H, Fireman EM, Mei-Zahav M, Prais D, Blau H. Induced sputum in the very young: a new key to infection and inflammation. Chest 2008; 133: 176-182.

88 Gutierrez JP, Grimwood K, Armstrong DS, et al. Interlobar differences in bronchoalveolar lavage fluid from children with cystic fibrosis. Eur Respir J 2001; 17: 281-286.

89 Balbi B, Pignatti P, Corradi M, et al. Bronchoalveolar lavage, sputum and exhaled clinically relevant inflammatory markers: values in healthy adults. Eur Respir J 2007; 30: 769-781.

90 Gibson PG, Grootendor DC, Henry RL, et al. Sputum induction in children. Eur Respir J 2002; 20: Suppl. 37, $44 \mathrm{~s}-46 \mathrm{~s}$

91 Mayer-Hamblett N, Aitken ML, Accurso FJ, et al. Association between pulmonary function and sputum biomarkers in cystic fibrosis. Am J Respir Crit Care Med 2007; 175: 822-828.

92 Armstrong DS, Grimwood K, Carzin R, Carlin B, Olinsky A. Lower airway inflammation in infants and young children with cystic fibrosis. BMJ 1995; 310: 1571-1572.

93 Armstrong DS, Hook SM, Jamsen KM, et al. Lower airway inflammation in infants with cystic fibrosis detected by newborn screening. Pediatr Pulmonol 2005; 40: 500-510.

94 Griese M, Latzin P, Kappler M, et al. $\alpha_{1}$-Antitrypsin inhalation reduces airway inflammation in cystic fibrosis patients. Eur Respir J 2007; 29: 240-250.
95 Tiddens HA, de Jong PA. Update on the application of chest computed tomography scanning to cystic fibrosis. Curr Opin Pulm Med 2006; 12: 433-439.

96 Tiddens HA. Chest computed tomography scans should be considered as a routine investigation in cystic fibrosis. Paediatr Respir Rev 2006; 7: 202-208.

97 Reinhardt N, Chen CIU, Loppow D, et al. Cellular profiles of induced sputum in children with stable cystic fibrosis: comparison with BAL. Eur Respir J 2003; 22: 497-502.

98 McElvaney N, Hubbard RC, Birrer P, et al. Aerosol $\alpha_{1^{-}}$ antitrypsin treatment for cystic fibrosis. Lancet 1991; 337: 392-394.

99 Rabin HR, Butler SM, Wohl MEB, et al. Pulmonary exacerbations in cystic fibrosis. Pediatr Pulmonol 2004; 37: 400-406.

100 Jones A, Elphick H, Pettitt E, Everard ML, Evans GS. Colistin stimulates the activity of neutrophil elastase and Pseudomonas aeruginosa elastase. Eur Respir J 2002; 19: 1136-1141.

101 Campbell EJ, Senior RM, McDonald JA, Cox DL. Proteolysis by neutrophils. Relative importance of cellsubstrate contact and oxidative inactivation of proteinase inhibitors in vitro. J Clin Invest 1982; 70: 845-852.

102 Ohbayashi H. Current synthetic inhibitors of human neutrophil elastase in 2005. Expert Opin Ther Pat 2005; 15: 759-771.

103 Owen CA, Campbell MA, Sannes PL, Boukedes SS, Campbell EJ. Cell surface-bound elastase and cathepsin G on human neutrophils: a novel, non-oxidative mechanism by which neutrophils focus and preserve catalytic activity of serine proteinases. J Cell Biol 1995; 131: 775-789.

104 Owen CA, Campbell EJ. The cell biology of leukocytemediated proteolysis. J Leukoc Biol 1999; 65: 137-150.

105 Owen CA. Proteinases and oxidants as targets in the treatment of chronic obstructive pulmonary disease. Proc Am Thorac Soc 2005; 2: 373-385.

106 Tremblay GM, Janelle MF, Bourbonnais Y. Anti-inflammatory activity of neutrophil elastase inhibitors. Curr Opin Investig Drugs 2003; 4: 556-565.

107 Attucci S, Gauthier A, Korkmaz B, et al. EPI-hNE4, a proteolysis-resistant inhibitor of human neutrophil elastase and potential anti-inflammatory drug for treating cystic fibrosis. J Pharmacol Exp Ther 2006; 318: 803-809.

108 Grimbert D, Vecellio L, Delepine P, et al. Characteristics of EPI-hNE4 aerosol: a new elastase inhibitor for treatment of cystic fibrosis. J Aerosol Med 2003; 16: 121-129.

109 Delacourt C, Herigault S, Delclaux C, et al. Protection against acute lung injury by intravenous or intratracheal pretreatment with EPI-HNE-4, a new potent neutrophil elastase inhibitor. Am J Respir Cell Mol Biol 2002; 26: 290-297.

110 Birrer P, McElvaney NG, Gillissen A, et al. Intravenous recombinant secretory leukoprotease inhibitor augments antineutrophil elastase defense. J Appl Physiol 1992; 73: 317-323.

111 Tetley TD, Smith SF, Burton GH, Winning AJ, Cooke NT, Guz A. Effects of cigarette smoking and drugs on respiratory tract proteases and antiproteases. Eur J Respir Dis Suppl 1987; 153: 93-102.

112 McElvaney NG, Doujaiji B, Moan MJ, Burnham MR, Wu MC, Crystal RG. Pharmacokinetics of recombinant secretory leukoprotease inhibitor aerosolized to normals 
and individuals with cystic fibrosis. Am Rev Respir Dis 1993; 148: 1056-1060.

113 Sallenave JM, Marsden MD, Ryle AP. Isolation of elafin and elastase-specific inhibitor (ESI) from bronchial secretions. Evidence of sequence homology and immunological cross-reactivity. Biol Chem Hoppe Seyler 1992; 373: 27-33.

114 Sallenave JM. The role of secretory leukocyte proteinase inhibitor and elafin (elastase-specific inhibitor/skinderived antileukoprotease) as alarm antiproteinases in inflammatory lung disease. Respir Res 2000; 1: 87-92.

115 Sallenave JM, Shulmann J, Crossley J, Jordana M, Gauldie J. Regulation of secretory leukocyte proteinase inhibitor (SLPI) and elastase-specific inhibitor (ESI/ elafin) in human airway epithelial cells by cytokines and neutrophilic enzymes. Am J Respir Cell Mol Biol 1994; 11: 733-741.

116 Maruyama M, Hay JG, Yoshimura K, Chu CS, Crystal RG. Modulation of secretory leukoprotease inhibitor gene expression in human bronchial epithelial cells by phorbol ester. J Clin Invest 1994; 94: 368-375.

117 Taggart CC, Cryan SA, Weldon S, et al. Secretory leucoprotease inhibitor binds to NF- $\mathrm{BB}$ binding sites in monocytes and inhibits p65 binding. J Exp Med 2005; 202: 1659-1668.

118 Weldon S, McGarry N, Taggart CC, McElvaney NG. The role of secretory leucoprotease inhibitor in the resolution of inflammatory responses. Biochem Soc Trans 2007; 35: 273-276.

119 Woods DE, Cantin A, Cooley J, Kenney DM, Remold-O'Donnell E. Aerosol treatment with MNEI suppresses bacterial proliferation in a model of chronic Pseudomonas aeruginosa lung infection. Pediatr Pulmonol 2005; 39: 141-149.

120 Gorrini M, Lupi A, Viglio S, et al. Inhibition of human neutrophil elastase by erythromycin and flurythromycin, two macrolide antibiotics. Am J Respir Cell Mol Biol 2001; 25: 492-499.

121 Berninger RW. Protease inhibitors of human plasma. $\alpha_{1^{-}}$ Antitrypsin. J Med 1985; 16: 23-99.

122 Chughtai B, O'Riordan TG. Potential role of inhibitors of neutrophil elastase in treating diseases of the airway. J Aerosol Med 2004; 17: 289-298.

123 Tebbutt SJ. Technology evaluation: transgenic alpha-1antitrypsin (AAT), PPL Therapeutics. Curr Opin Mol Ther 2000; 2: 199-204.

124 Cowden DI, Fisher GE, Weeks RL. A pilot study comparing the purity, functionality and isoform composition of alpha-1-proteinase inhibitor (human) products. Curr Med Res Opin 2005; 21: 877-883.

125 Karnaukhova E, Ophir Y, Golding B. Recombinant human alpha-1 proteinase inhibitor: towards therapeutic use. Amino Acids 2006; 30: 317-332.
126 Louie SG, Sclar DA, Gill MA. Aralast: a new $\alpha_{1}$-protease inhibitor for treatment of $\alpha$-antitrypsin deficiency. Ann Pharmacother 2005; 39: 1861-1869.

127 Dirksen A, Dijkman JH, Madsen F, et al. A randomized clinical trial of $\alpha_{1}$-antitrypsin augmentation therapy. Am J Respir Crit Care Med 1999; 160: 1468-1472.

128 Wewers MD, Casolaro MA, Sellers SE, et al. Replacement therapy for alpha 1-antitrypsin deficiency associated with emphysema. N Engl J Med 1987; 316: 1055-1062.

129 Wewers MD, Casolaro MA, Crystal RG. Comparison of alpha-1-antitrypsin levels and antineutrophil elastase capacity of blood and lung in a patient with the alpha-1antitrypsin phenotype null-null before and during alpha-1-antitrypsin augmentation therapy. Am Rev Respir Dis 1987; 135: 539-543.

130 McElvaney N, Nakamura H, Birrer P, et al. Modulation of airway inflammation in cystic fibrosis. J Clin Invest 1992; 90: 1296-1301.

131 Wright G, Carver A, Cottom D, et al. High level expression of active human alpha-1-antitrypsin in the milk of transgenic sheep. Biotechnology (N Y) 1991; 9: 830-834.

132 Hubbard RC, Crystal RG. Strategies for aerosol therapy of alpha 1-antitrypsin deficiency by the aerosol route. Lung 1990; 168: Suppl., 565-578.

133 Martin SL, Downey D, Bilton D, Keogan MT, Edgar J, Elborn JS. Safety and efficacy of recombinant $\alpha_{1}$-antitrypsin therapy in cystic fibrosis. Pediatr Pulmonol 2006; 41: $177-183$.

134 Spencer LT, Humphries JE, Brantly ML. Antibody response to aerosolized transgenic human alpha -anti- $^{-}$ trypsin. N Engl J Med 2005; 352: 2030-2031.

135 Vogelmeier C, Kirlath I, Warrington S, Banik N, Ulbrich E, Dubois RM. The intrapulmonary half-life and safety of aerosolized alpha1-protease inhibitor in normal volunteers. Am J Respir Crit Care Med 1997; 155: 536-541.

136 Berger M, Konstan MW, Hilliard JB. Aerosolized prolastin $\left(\alpha_{1}\right.$-protease inhibitor) in CF. Paediatric Pulmonology 1995; 20: 421.

137 Griese M, von Bredow C, Birrer P. Reduced proteolysis of surfactant protein A and changes of the bronchoalveolar lavage fluid proteome by inhaled $\alpha_{1}$-protease inhibitor in cystic fibrosis. Electrophoresis 2001; 22: 165-171.

138 Griese M, von Bredow C, Birrer P, Schams A. Inhalation of $\alpha_{1}$-protease inhibitor in cystic fibrosis does not affect surfactant convertase and surface activity. Pulm Pharmacol Ther 2001; 14: 461-467.

139 Cantin AM, Berthiaume Y, Cloutier D, Martel M. Prolastin aerosol therapy and sputum taurine in cystic fibrosis. Clin Invest Med 2006; 29: 201-207.

140 Gibson R, Burns JL, Ramsey BW. Pathophysiology and management of pulmonary infections in cystic fibrosis. Am J Respir Crit Care Med 2003; 168: 918-951. 